Matters arising: Can transnational corporations leverage systemic change towards a "sustainable" future?

Response to Folke et al. Transnational corporations and the challenge of biosphere stewardship. Nat. Ecol. Evol. 3, 1396-1401 (2019).

Authors: Anselm Schneider ${ }^{1 *}$, Jennifer Hinton ${ }^{2}$, David Collste ${ }^{2}$, Tais Sonetti González, Sofia Valeria Cortes Calderon, Ana Paula Aguiar ${ }^{2}$

*Corresponding author: anselm.schneider@sbs.su.se

${ }^{1}$ Stockholm Business School, Stockholm University, Sweden

${ }^{2}$ Stockholm Resilience Centre, Stockholm University, Sweden 
We welcome the idea that transnational corporations (TNCs) can play a central role in the protection of the biosphere recently contributed by Folke et al. ${ }^{1}$. It is certainly crucial to understand how TNCs affect the biosphere. While the authors provide a comprehensive overview of the impact of TNCs on the biosphere and propose some pathways through which TNCs might contribute to the stabilization of the Earth system, we argue for increased attention to several crucial intrinsic features of TNCs that are problematic for the central question posed by the paper "Can TNCs leverage large-scale systemic change, accelerate positive transformations towards sustainability, and contribute to a safe operating environmental space for humanity?" (Folke et al., 2019, p. 1398).

\section{Intrinsic features of TNCs}

First, currently the incentive structures for TNCs, which are largely determined by global financial markets ${ }^{2}$, demand continuous profits in order to deliver high returns on investment ${ }^{3}$. Folke et al. (2019, p. 1401) concede that TNCs in many documented cases meet profit expectations by instigating "excessive, wasteful consumption founded on a fossil-fuel driven economy". However, abstaining from such practices would for many TNCs (for instance in the fossil fuel, mining, and garment industries) imply not only a minor adjustment of their business model, but a discontinuation of their core purpose and structure. While the idea of "corporate biosphere stewardship" as a "new business logic with the purpose of shepherding and safeguarding the resilience of the biosphere for human well-being” (Folke et al., 2019, p. 1401) is appealing, it seems to implicitly build on the assumption of a "business case for corporate sustainability" where businesses can make money through contributing to environmental integrity and social equity. This assumption is unlikely to apply to every business context, and has not been empirically supported ${ }^{4}$. Biosphere stewardship and social equity are in many cases opposed to the profit expectations of the global financial system, and thus the incentives for TNCs to engage in biosphere stewardship are limited. There is a contradiction between the 
vision of a sustainable and just world ${ }^{5,6}$ and the disproportional concentration of market share, wealth and power in a few TNCs and their shareholders. Therefore, ownership and investment structures of TNCs pose a key challenge, if not a barrier, to their potential to act as biosphere stewards.

Second, TNCs typically operate in geographical areas that have weak political institutions (including corruption, human rights violations, and even civil war; see, e.g., ${ }^{7}$ ). Under these conditions TNCs can capitalize on negative externalities, which are borne by the biosphere and the citizens of the TNCs' host countries ${ }^{8}$. The utilization of governance gaps, which are often a result of colonialism by the Global North ${ }^{9}$, by TNCs to their benefit ${ }^{8}$ can exacerbate social and economic inequalities between high-income countries, where most TNCs are headquartered, and middle-to-low-income countries, which often host TNCs' activities. In this way, they actively erode local modes of biosphere stewardship, as is the case with mining TNCs in the India ${ }^{10}$ and fossil fuel TNCs in Nigeria ${ }^{11}$. While Folke et al. (2019) explicitly mention that "people, nations and the global economy are intertwined with the biosphere" (p. 1401) and refer to the inequalities created by the global economy, their account of the role of TNCs in biosphere stewardship overlooks these problematic aspects.

\section{Problems with trusting biosphere "stewardship" to TNCs}

In our eyes, the overly optimistic perspective of TNCs presented by Folke et al. (2019) harbours several dangers. First, portraying TNCs as actors who have the potential to "leverage largescale systemic change" veils the fact that the TNC is one of the centrepieces of systemic dynamics causing the current biosphere crisis. Acknowledging this makes it clear that system change would also require a major structural transformation of TNCs, if not the search for alternative forms of organizing the economic system, which goes beyond the emerging features presented by Folke et al. (2019). 
Second, while explicitly mentioning the importance of effective and improved governmental regulation, the authors suggest a rather unproblematic relationship between TNCs and national and global regulation. However, the influence of TNCs on democratic political processes and regulatory efforts across scales (be it through lobbying, tax evasion, or corruption ${ }^{12}$ ) suggests that there is not so much of a congruence of goals as a sacrificing of the public interest in service of private profit for TNCs. Folke et al. (2019) do not seem to acknowledge the immense social and political power wielded by $\mathrm{TNCs}^{13}$ and the fact that their interference with political processes is among the main reasons that stricter regulations of their practices are not implemented.

Third, and crucially, we believe a rather unbalanced assessment of potential contributions of TNCs to biosphere stewardship reinforces the economistic narrative of a mutually beneficial relationship between global capitalism, biosphere stewardship, and social progress, which seemingly does not hold. Accomplishing the "deep transformation based on a fundamental reorientation of human values, equity, behavior, institutions, economies, and technologies“14 that is necessary for re-entering a safe operating space for humanity is unlikely to be found within the traditional narrative of global capitalism ${ }^{15}$, of which TNCs are some of the most powerful representatives - and supporters.

We suggest academia should engage in the quest for, and envisioning of, alternative economic paradigms that safeguard the needs of all people, promote a less unequal world and ensure the re-entering of a safe operating space for humanity. This requires an understanding of the lockins, complexities and resilience of the current dominating economic system, to avoid proposing solutions which might only reinforce the root causes of the current situation. 


\section{References}

1. Folke et al., Transnational corporations and the challenge of biosphere stewardship. Nature Ecology \& Evolution 3, 1396-1401 (2019).

2. Davis, G. F. Managed by the markets: How finance re-shaped America (Oxford University Press 2009).

3. Stout, L. A. The shareholder value myth: How putting shareholders first harms investors, corporations, and the public. Berrett-Koehler Publishers (2012).

4. Adler, P. The 99\% economy. Oxford: University Press (2007).

5. Raworth, K. Doughnut economics (White River Junction: Chelsea Green Publishing 2018).

6. Leach et al., Equity and sustainability in the Anthropocene: A social-ecological systems perspective on their intertwined futures. Global Sustainability, 1, E13. doi:10.1017/sus.2018.12(2018)

7. Guidolin, M., \& La Ferrara, E. (2007). Diamonds are forever, wars are not: Is conflict bad for private firms?. Am. Econ. Rev. 97, 1978-1993 (2007).

8. Muchlinski, P. Social and Human Rights Implications of TNC Activities in the Extractive Industries. Transnational Corporations 18, 93-104 (2009).

9. Acemoglu, D., \& Robinson, and J. A. Why nations fail: The origins of power, prosperity and poverty (Suffolk: Clays 2012).

10. Kraemer, R., Whiteman, G., \& Banerjee, B. Conflict and astroturfing in Niyamgiri: The importance of national advocacy networks in anti-corporate social movements. Organ. Stud., 34, 823-852 (2013). 
11. Muchlinski, P. T. (2001). Human rights and multinationals: Is there a problem? Int. Aff. 77(1), 31-47 (2001).

12. Fuentes-Nieva, R. \& Galasso, N. Working for the few: Political capture and economic inequality. (Oxford, UK: Oxfam GB 2014).

13. Phillips, N. Power and inequality in the global political economy. Int. Aff. 93 (2), 429444 (2017).

14. Steffen, W., Rockström, J., Richardson, K., Lenton, T. M., Folke, C., Liverman, D., ... \& Donges, J. F. Trajectories of the Earth System in the Anthropocene. Proc. Natl Acad. Sci. 115, 8252-8259 (2018).

15. Göpel, M. The great mindshift. Springer Nature: https://doi.org/10.1007/978-3-31943766-8 (2016). 